February - 2009

\title{
Increasing Public Access to University Qualifications: Evolution of The University of the West Indies Open Campus
}

\author{
Michael L. Thomas and Judith Soares \\ The University of the West Indies
}

\begin{abstract}
This paper traces the evolution of The University of the West Indies' Open Campus (UWIOC), which is expected to expand service and increase access to the underserved communities of the Eastern Caribbean. At present, UWI, which caters to the needs of the 16 far flung countries of the Commonwealth Caribbean, has not been able to fully serve these countries, the UWI-12, in a way that is commensurate with their developmental needs. Historically, the institution has been dominated by campus-based education, and its three campuses have been poles of attraction for scholars and scholarship to the significant advantage of the countries in which they are located: Jamaica, Trinidad and Tobago, and Barbados.

The University's creation of an open campus, a fourth campus, enables it to expand its scope, enhance its appeal, and improve the efficiency of its services to individuals, communities, and countries. This new campus, a merger of UWI's Outreach sector, which comprises the School of Continuing Studies, the Tertiary Level Institute Unit, and The UWI Distance Education Centre, will have a physical presence in each contributing country and will function as a network of real and virtual modes to deliver education and training to anyone with access to Internet facilities.
\end{abstract}

\section{Introduction}

Expansion of higher education in the Caribbean done in a rational way, with sensitivity to our current realities and with a clear commitment to quality is a winning option for the region and its peoples. (Bhoendradatt Tewarie, 2007)

The University of the West Indies is one of three regional universities in the world, the other two being the University of the South Pacific and the University of the Indian Ocean. Established in 1948 as a regional university and serving a student population of 35,000, UWI caters to the higher educational needs of the 16 countries of the Commonwealth Caribbean: Anguilla, Antigua \& Barbuda, (the) Bahamas, Barbados, Belize, (the) British Virgin Islands, (the) Cayman Islands, 
Dominica, Grenada, Jamaica, Montserrat, Republic of Trinidad \& Tobago, St. Kitts \& Nevis, St. Lucia, St. Vincent \& the Grenadines and (the) Turks \& Caicos Islands.

The UWI began its experimentation with distance education as early as 1958 with the establishment of the Radio Education Unit (REU) on the Jamaica campus. Although the Unit was not a serious medium of adult education, it nonetheless had the potential to make a "vital and unique contribution" to that field in the Caribbean (Fergus, Bernard, \& Soares, 2007, p.77). From its inception, the REU was responsible for producing radio programmes, which were used in Jamaica and throughout the Caribbean in schools and teachers' training colleges. Recordings were also sent to various radio stations throughout the region. More serious attempts at distance education came later in the 1970s with the introduction of the prototype Challenge Examination Scheme, which was a new concept in distance education for UWI. In 1983, Challenge was absorbed into The University Distance Teaching Experiment (later Enterprise) (UWIDITE) which, in 1996, evolved into the University Distance Education Centre (UWIDEC), thereby making the institution a dual mode operation. This new development formalised UWI's determination to explore the usefulness of a telecommunications network for education, outreach, and public service, which is of critical importance in the Anglophone Caribbean region as it is spread over 99,215 square miles and is separated by two thousand miles of water. However, despite the new developments in distance education, UWI fell short of providing higher education to those countries of the Eastern Caribbean, referred to as The UWI-12, not only because these countries exist on the periphery of the campuses in Jamaica, Trinidad and Tobago, and Barbados, but also because the cost of higher education is prohibitive for some of their residents. So while we could argue that higher education has a history of fruitful experiments with distance learning, as demonstrated by the use of technology to deliver programmes beyond the physical campuses, we must also recognize that problems of infrastructure and access remain unresolved.

In fact, Gulati (2008), with reference to UWI, noted that distance education (DE) was still sidelined by face-to-face teaching faculty, who viewed it as an add-on and voiced fears that they were "giving away" their intellectual property. She concludes that the face-to-face faculty did not view their distance teaching experience as a positive influence on their careers, nor did they identify with distance education's goal of widening access. Faculty resistance to DE is not new. In this respect, Olcott and Wright (1995) have observed that faculty members appear reluctant to participate. Ellis (2000) supports this point by arguing that faculty members view it as time consuming and question changes to already busy workloads. Perraton (as cited in Hope, 2006) confirms that in the case of UWI there was little anyone could do to support and expand DE when faculty members had tenure, job descriptions did not include distance education, and heads of department were unenthusiastic.

In examining some of the educational traditions which may have relevance to discussion of barriers to access, the educational experience of the Caribbean may be divided into four periods. These discrete periods are as follows: "prior to 1948, between 1948 and 1969, 1970 to 1995 and 1996 to present" (Roberts, 2002, p. 6). However, it could be argued that the period from 2007 marked the beginning of a fifth discrete period in the discourse on barriers to access. In relation to this, several barriers to tertiary education access have been identified by, for example, Roberts 
(1999), Marrett (2000), Garcia (2000), and O'Neal and Davies (2000). According to Roberts (2002), these include the following: space (geographical and accommodation); cost (development, delivery, and travel); population size and economies of scale; technology; attitude of producers and consumers; the structure of opportunity; administrative leadership; and gender. Cost is frequently adduced as a factor that inhibits less well-off students from proceeding with study. However, to minimize the costs of study is not necessarily to overcome the barriers to access. The case of Germany can be highlighted, where efforts to improve access have run counter to a strongly entrenched academic tradition. In this respect, Berggreen-Merkel (as cited in Skillbeck \& Connell, 2000) notes that "keeping up the academic standards of schools and higher education institutions vs. open access and equity - this seemed to have been the political question in the past decades in Germany" (p. 28). Recent research in Australia suggests that a policy enabling universities to derive more income from fees for non-research, professional postgraduate courses and from employed people who can afford them has, as an unintended consequence, meant that a number of academically qualified people who cannot afford the fees are unable to enroll, thereby effectively debarring them from entry into certain professions (Anderson et al., 1998). And in the international research literature, socio-economic conditions affecting student access to higher education have been a strong concern for several decades, greater in some countries than others, muted at times, but persistent. Research and policy measures have centred on the following: the disparity of opportunity among social classes with a recurring emphasis on low socio-economic status, the concept of cultural as well as economic capital, rural areas and economically disadvantaged regions or areas, and the interactions among these factors (Skilbeck \& Connell, 2000). Sometimes, attention has focused on the "second chance" principle, i.e., increasing opportunities for mature students. The literature has shown that this is variable across national higher education systems. Returning to the Anderson study, one bright light he detected in the Australian environment is the great expansion of enrolments by mature students (evening classes, distance education). There is a modest correlation in the student population between greater or mature age and low socio-economic status. Distance education, wherever it has been seriously promoted, has increased opportunities for mature age entry to higher education, including those who lack formal qualifications and those from lower socio economic groups. But access once gained does not guarantee that all problems will be solved.

In the context of the above, the establishment of a fourth campus, an open campus, should be seen as a radical reconceptualization of higher education in the Caribbean. It is not to be seen as an add-on to UWI but is to be understood as a part of a reengineering of the educational infrastructure in order to establish a relevant and appropriate entity expected to resolve issues of access.

The proposed organizational structure of UWI's Open Campus is designed to expand the scope of UWI by increasing the range, reach, and access to university programmes and services by students from the relevant target groups. The aim is to create a division dedicated to the development of pre-university and professional courses and programmes such that they provide the opportunity for people in the region to pursue various routes to access university education. In addition, community focused teaching and research units will collaborate to provide a wider range of preparatory and developmental programmes for an increasing number of applicants, 
including those who would either not have had the opportunity for access or those who, through lack of sensitization, may not have pursued the means of doing so. Further, the redesigning of programmes offered at the online delivery sites will make preparatory programmes available to a wider range of people and will open up opportunities for access to higher education. However, it is our view that institutions must consider the advice of Skilbeck \& Connell (2000), who argue that the desire to open up admission procedures must be tempered by a realistic appraisal of student capabilities and the readiness and capacity of institutions to provide suitable study environments.

In this paper, our definition of access coincides with that of the Council of Europe project on Access to Higher Education in Europe, where access is defined by Woodrow (1996) in this way:

- greater participation in higher education of good quality;

- the extension of participation to include currently under-represented groups; and

- a recognition that participation extends beyond entry to successful completion. (p. 7)

Against this background, this paper discusses the evolution of UWI's Open Campus, which came on stream in the 2008/2009 academic year.

\section{Addressing Issues of Access in the Eastern Caribbean}

According to Malik, Belawati, \& Baggaley (2005), whilst distance learning has the potential of impacting all levels of education, tertiary education is the level at which the maximum benefits could be achieved in terms of economic impact. Although Asia and the Pacific were used as examples, the same is true for the Caribbean in terms of the potential of deploying appropriate emerging Distance Learning Technologies (DLTs) to provide high-quality tertiary education that is accessible and affordable to population segments and that supports developing countries in their desire to convert their ample human resources into human capital. This, in turn, will improve their socio-economic status. However, Lewins and Stuart (1991) propose that educational provisions in developing countries were limited due to their governments' failures to recognise and address the issues of access, culture, and gender gap, which affected poorer population groups.

The Organisation of Eastern Caribbean States (OECS) Development Charter (2002) makes a firm commitment to ensuring that their education system is structured to produce the positive results required for making their economies more efficient. However, despite the developments in the education system over the years, there remain concerns about six ongoing problems: the low levels of educational achievement, declining rates of completion at the primary level, increasing levels of functional illiteracy/semi-literacy at the primary level, the high drop-out rate for boys, the virtual lack of problem solving skills among graduates of the education system, and significantly, the small percentage of the population who access higher education and participate in adult and continuing education (2002, p. 11). 
Such concerns are also recorded in The Organisation of Eastern Caribbean States Education Reform Unit (OERU) Strategic Plan 2001-2010 (2001), which states the following:

In the OECS countries, only between $3-7 \%$ of the population achieve a tertiary level of education....If we are to reach the level of $17 \%$ targeted for 2010, then a great deal of effort must be put into increasing access to tertiary institution or enabling learning through distance education or other new technological means. (p. 9)

Although the Plan points to general principles guiding reforms to education in the states of the Eastern Caribbean, it speaks specifically to the issue of access. In this regard, it proposes supporting and assisting member states' efforts to increase access by children and adults to all levels of education (pre-school, primary, secondary, and tertiary), including access to education by children with special needs and by the out-of-school population. In addition, it proposes more emphasis be placed on the reduction of inequity and mitigation of poverty in the education system. To achieve its objective, The OERU has a stated commitment to concentrate its activities in seven strategic programming areas, one of which bears relevance to tertiary education/postsecondary education, in relation to harmonization of governance structures and programme development, including diversification and evaluation. This programme area, already being defined through the European Development Fund/Human Resource Development Programme, will continue to promote standardization and harmonization of programmes and accreditation practices among tertiary/postsecondary institutions in member states. Areas of operation will include inter alia the promotion of relevant courses and programmes to enhance the economic development of the sub-region. Within the context of reforming tertiary, adult, and continuing education, the OECS Education Reform Unit lists four objectives on its Web page:

- To transform tertiary education into the engine of human resource development and knowledge generation in the sub-region.

- To facilitate the consolidation of technology transfer in the sub-region.

- To provide educational programmes for all persons who missed or were not afforded the opportunity to complete formal primary or secondary education.

- To provide the opportunity for educational renewal and advancement for all citizens with the relevant educational background to continue their education throughout life.

The OERU also emphasizes increasing access:

Tertiary education is underdeveloped within the OECS. Any new thrust must be mandated to provide for a higher percentage of the population thereby decreasing the tendency of OECS nationals to migrate in search of tertiary education. This means expanding tertiary education opportunities within the OECS. At the same time, the under- 
representation of females in Science and Technology and the deprivation of rural residents require attention.

The unit further points to the partnership arrangement necessary for the achievement of these stated objectives when it prescribes "...a partnership involving all the beneficiaries in order to ensure that the best relevant quality education is delivered. Only a national effort that maximizes government, private sector, personal, and external support can provide the needed expansion and improvements." From this statement, we can conclude that the OECS recognizes the central role that education, particularly tertiary education and lifelong learning, has to play in the enhancement of their sub-regional development. This determination, no doubt, played a part in encouraging UWI and other regional educational institutions to give serious thought to resolving issues of educational attainment for the peoples of the region.

The decision to deliver distance education programmes by regional institutions such as UWI at the undergraduate, graduate, and postgraduate levels was geared toward this objective and hence the bifocal nature of its response should come as no surprise. This bifocal approach meant firstly, widening student access, and secondly, responding to the needs of those students in the noncampus countries who could not afford to move to a campus country. According to Sherlock \& Nettleford (1990),

The University has a responsibility itself to assess those perceived needs with a view to satisfying them in ways that will provide the region with resourceful, thinking graduates who will be able to rid the region in due course of the material dispossession, spiritual enfeeblement and cultural dependency by which it has been afflicted generation upon generation. (p. 279)

The responsibility therefore falls squarely on the shoulders of UWI to respond to the challenges faced by the sub-regional sector for an appropriate human resource development response.

The Caribbean governments have made tremendous efforts to facilitate increased access to tertiary education for its regional citizens, which has placed a tremendous burden on the Exchequer and has further exacerbated inequality within their societies. The typical approach has been for the taxpayer to shoulder the bulk of the cost of tertiary education. In the case of Barbados, the government pays the full cost of tuition and the students' economic costs. In the case of Jamaica and Trinidad and Tobago, even though the governments pay the full economic costs for students, the last two decades have seen attempts to transfer some of the costs of tertiary education to students; however, lower income students have little ability to finance their tertiary education from family income. The implication of this, for example in Jamaica, has been that the imposition of tuition fees while placing a financial burden on lower income students, has forced the Students' Loan Bureau to discontinue lending for non-tuition tertiary education expenses. Wint (2005) makes the following point: 
The student loan systems that have emerged in the Caribbean place barriers to the participation of the poorer residents of the respective countries because the mortgage-type loans that emerge from these systems do not address the risk-aversion of poor prospective borrowers, and these loan systems do not adequately deal with the challenges poorer residents confront in finding loan guarantors. (p. 17)

It is in this context that UWI is in a position of offering education at affordable rates through particular arrangements and payment schemes, which favour the student. The strategy then for resolving issues of human resource development was to establish and operate an open campus, which would achieve the following: improve access to its programmes; create a student-centered learning environment; establish a viable and sustainable financing mechanism; design and implement an administrative and organizational structure; formulate policy for managing, developing, and implementing open and flexible learning; and establish policy for managing/building inter-institutional relationships/partnerships.

\section{Emerging Organizational Models}

Campus-based education has dominated UWI's history, and its three campuses have attracted scholars and scholarship, which has benefitted the countries where they are located. By contrast, the other 12 countries have not been served in relation to their developmental needs. Bothersome aspects of this lower service have been marked by a modest intake of students to the institution from, and in, the 12 countries without campuses as well as the limited number and types of programmes that can be pursued in the distance mode. Additionally, these countries have had less automatic access to consultancy resources and to research capacity than the countries where the campuses are located. These disadvantages have been exacerbated by recurrent inefficiencies in the management and delivery of programmes in the distance mode as well as by the outmoded technology and policies that supported them.

Historically, UWI has sought to address these shortcomings in a variety of ways, including the creation of offices and boards with specific responsibility for the needs of the non-campus countries. The Board for Non-Campus Countries and Distance Education (BNCCDE), created in 1996, was intended to be the agency which would address these deficiencies to provide "... a stronger more unified presence in non-campus countries," and therefore enable the University to demonstrate that its work in these countries has equal priority with its work on the campuses (Marshall,1997/1998, p. 2). The Board was expected to co-ordinate and to manage the relationship between all outreach providers, particularly the School for Continuing Studies, the Tertiary Level Institutions Unit, and the Distance Education Centre. Marshall (1997/98), then Chairman of the Board, expressed the view that "with all units under one roof, hopefully we will eliminate the fragmentation and inefficiencies of earlier arrangements and create opportunities for the development of a focused and integrated approach to outreach activity" (p. 2). Subsequent to this, staff in The UWI Distance Education Centre (UWIDEC) began to re-engineer the delivery 
systems for distance education to improve their efficiency. Their efforts required the vesting of authority in UWIDEC, which was normally exercised by faculties. In the same period, the School of Continuing Studies embarked on an initiative to shift the status of its programmes to add regional and institutional recognition to what had been only local level recognition of qualifications. The third department addressing issues was the Tertiary Level Institutions Unit (TLIU), which sought to improve the quality of performance and facilitate the acceptability of students completing studies in national and community colleges. Essentially, its mission is to enhance access to tertiary education in the region by linking the University's resources, programmes, and services to the development of tertiary education institutions in The UWI-12 countries and to those sites located off-campus in the campus countries. Collectively, all three departments under the BNCCDE have been pursuing pathways to overcome deficiencies and to meet contemporary demands in the face of growing competition from an increasing number of tertiary education providers.

It should be noted that the primary reasons for these persistent shortcomings were that the offices and boards did not control the academic, administrative, or financial resources that could correct them; programmes were being delivered as off-shoots of primarily campus-generated activities; and the secondary status of the offices and boards caused adverse affects. Correcting this situation requires that there be an academic authority capable of independent decisions on the nature of programmes appropriate for the specific clientele. It should be able to manage the delivery of programmes and services in the distributed environment of all contributing countries without managerial reference to faculties and departments that have primary responsibility to the three campuses.

The UWI's decision to establish an open campus was meant to address the shortcomings experienced over the years. A series of consultations was undertaken by UWI in the UWI-12 countries to ascertain the developmental needs and plans of each of the countries and to determine ways in which UWI could better serve them. This process helped to inform the institution's decision to establish a separate entity because it provided worthwhile information for the construction of a five-year strategic plan. The data from these sources revealed a strong unsatisfied demand for quality higher education services delivered flexibly by UWI among the sub-region's communities, special professional and vocational groups, and those persons in campus countries who were unable to participate in the timetabled environment of a conventional campus by virtue of their location or their lifestyle.

Therefore, the impetus for creating a campus, rather than a department or faculty, a new office, or an administrative layer lies in the fact that a campus is the highest level of academic, financial, and administrative organization within the University. For a campus, in the context of the Caribbean, the statutes and ordinances of UWI establish a council, an academic board, and a financial committee. This gives it autonomy from other campuses while preserving the membership of the campus in the academic community through its special relationship with the University Council, the Senate, the Board for Undergraduate Studies, the Board for Graduate Studies and Research, the University Finance and General Purposes Committee, and other such governance instruments. 
Perhaps the most important decision with respect to creating the new entity is the choice of institutional model. This decision will obviously have a wide impact on the policies needed as well as planning and management strategies. The institutional model must reflect the situation of the institution, demands from students, and access to technology, to name a few concerns. It must be borne in mind that there is no single model, and the opinion is voiced in many quarters that the best approaches have yet to be found.

\section{Evolution of The UWI Open Campus}

In April, 2007, the Council of The University of the West Indies approved the development of an Open Campus. In recognizing the importance of such an entity, the Vice-Chancellor described this development in Caribbean Net News (2008) as "an essential strategic element of the University's ongoing five-year strategic plan to transform its curricula and education systems, as well as to enhance the postgraduate programmes and research productivity." The Vice-Chancellor commented further:

The Open Campus will insist on quality education relevant to the region, student-centredness, student-friendly services, and the creation of knowledge and outreach to the Caribbean Community outside the walls of the University, particularly in the Eastern Caribbean, Belize, the Cayman Islands and in rural areas in campus countries.

The Vice-Chancellor's remarks can be viewed as recognition of the need to improve the previous efforts by the institution to offer distance education across a region separated by time and space. His comments must also be seen within the context of streamlining the operations of the outreach sector to locate the student at the centre of learning, teaching, and administration and to provide greater access to the peoples of the region for whom there have been serious barriers.

The regional use of distance education had its genesis within UWI from as early as 1977. At this time, the Challenge Examination Scheme, introduced at the Mona campus, enabled students in non-campus countries to register to sit Part I of the degree programme in the social sciences without attending classes on a campus or being provided with any significant support, such as library facilities, from the University. After completing at least four of the five required courses, students would then enter Part II of their programme on a campus. While the Scheme was limited in its reach, it, nonetheless, provided an opportunity for students to access university education in a way that was advantageous to them. For example, there was no loss of income for the students; neither did they have to leave their families. As well, Sherlock and Nettleford, (1990) point out that there was no replacement cost for employers and both students and/or governments were spared economic and maintenance costs for one year. However, over its six years, the Scheme, while contributing to the enrichment of intellectual life and the reduction of costs associated with accessing a university education, did not fully satisfy a growing pool of secondary school graduates and those seeking to expand their knowledge base and professional qualifications. 
The absorption of the Scheme into The University Distance Teaching Experiment (UWIDITE) in 1983 signalled UWI's intention to take distance education to a higher level. Lalor and Marrett (1986) describe UWIDITE as "one of the first experiments in the developing world to provide education and outreach by means of an interactive telecommunications network" (p. 72). According to Carrington \& Thomas (2001), the main features of the delivery model were as follows:

- There was no face-to-face classroom teaching at the university.

- The classroom lectures were replaced by audio-conferences. This required attendance at pre-scheduled times at the university teleconference site in one's own country.

- Printed course materials supported the teleconferences.

- Face-to-face tutorials were provided in all five participating countries and from time to time campus-based lecturers visited these University centres to provide further academic support. (p. 7)

Initially, the system linked the three campuses to two non-campus countries (St. Lucia and Dominica). Other sites were added so that by 1993, 11 non-campus countries were being served as well as several off-campus sites in Jamaica and Trinidad \& Tobago. At the end of the project, UWI assumed full responsibility for the programme retaining the acronym but with the word Experiment changed to Enterprise. Although the experiment/enterprise was useful in the delivery of $\mathrm{DE}$, it nonetheless suffered from limitations; for example, the over concentration on teleconferencing as its main facet of delivery ignored the possibility of how its distance education activities could have been more closely related to its computer/communications facilities. Lalor \&Marrett (1986) again noted that UWIDITE was particularly appreciated in the non-campus countries, which were greatly concerned with strengthening their education and training systems and improving educational facilities albeit with limited resources. These pioneers of the system identified the availability of funds as one among a number of other problems, including "the small size of certain demands which makes the economic viability of conventional training programmes uncertain; the difficulty of recruiting staff to work in relatively isolated environments; and the isolation from which staff works" (p. 72). These problems "could be ameliorated by the use of telecommunications" (p. 72). In spite of these limitations and based on its usefulness, it was felt that distance education would be better served if UWIDITE was more integrated within the UWI system as an independent operation yet maintaining links with the faculties to allow a more faculty-driven approach. Essentially, the DE operation would be administratively independent but academically integrated. This thinking gave birth to what became The University of the West Indies Distance Education Centre (UWIDEC) in 1996 as a means of mainstreaming DE activities.

However, it was in 1992 that the University Academic Committee (UAC) decided that The University of the West Indies should become a dual mode institution (UAC decision, 1992) to increase access, respond to environmental factors, and facilitate the pursuit of its mission to unlock the potential of the peoples of the region. A report by Renwick, Shale, \& Rao (1992) explicitly provided the policy justification and guidelines for making distance education an 
integral part of the University's higher education thrust. The decision to become a dual mode institution assumed the following:

- Students would be able to access programmes in face-to-face or in distance mode or a combination of both.

- Staff would treat the development and delivery of programmes by distance as an integral part of their work and have this suitably recognised by their faculties.

It was also assumed that student centredness, quality, and cost effectiveness would be hallmarks of all University programmes and not just those delivered in distance mode, and further, that sufficient resources would be allocated by the university's administration and faculties to enable attainment of these goals. The motivation for engaging in dual mode education differs from institution to institution, and there are examples of notable success as well as of failures to fulfill the expectations of the learners engaged in distance mode study.

The decision to deliver undergraduate, graduate, and professional programmes by face-to-face and by distance mode was shaped by the strategic direction that the University had set for itself in its Development Plan, 1990-2000. The plan included funding for DE in the 1993-1996 budgets, and in 1993 a Board for Distance Education (predecessor to BNCC\&DE) was established to direct the process of educational planning and programme implementation. The aim of the decision was to widen student access and raise the quality of programme and course offerings and, by so doing, to increase the responsiveness of the University to the pressing demands of the contributing governments. In the period preceding the decision, the governments of the noncampus countries had been demanding a greater part of what the University could contribute to the economic and social development of the sub-region.

The case of The University of the West Indies (UWI) provides an excellent example of typical reasons for the introduction of dual mode education and of the problems that may beset attempts to integrate the two modes unless adequate attention is paid to the issues raised in the ensuing paragraphs. John Daniel, reflecting on his tenure as president of Laurentian University, a multicampus dual-mode institution serving North-Eastern Ontario from its main campus in Sudbury, noted the difficulty inherent in managing dual mode type institutions. Daniel (2007) remarked that "watching the faculty struggle - or fail to struggle - to serve both on-campus and off-campus students gave me a conviction, which has never left me, that managing dual-mode operations is extremely difficult. Whatever arrangements are put in place seem inherently unstable" (p. 3). He was quick to point out that "Too much centralization of the organization of ODL and the faculty feel disempowered; too much delegation of responsibility for ODL to individual academics and student support becomes inconsistent" (p. 3). What Daniel has identified has relevance to UWI as a dual-mode institution.

In 1996, the operations of UWIDITE were incorporated into the UWI Distance Education Centre (UWIDEC), heralding the expansion of DE programmes, methodologies, and staffing. The mission statement crafted at the time for the Distance Education Centre reads as follows: 
The Distance Education Centre of the UWI is dedicated to becoming a centre of excellence in itself and a catalyst for excellence in distance education throughout the University, to developing and delivering quality programmes by distance, and in so doing, meeting the higher education learning needs of an ever widening population of students, in order to contribute to the University's mission of unlocking the potential of the peoples of the Region. (The University of the West Indies, 1996b, p.3)

It is clear that the Centre's mission had been conceived to fit into the strategic intent of the University to serve the region in more inventive ways. However, in 1996, faced with a new mandate to play a greater role in regional human development, "UWI embarked upon a process of transition to dual mode operation, but the process was fraught with difficulties" (Morgan, 2000, p. 108).

\section{Table 1}

Status of UWIDEC Policy Points (1998)

\begin{tabular}{|c|c|c|}
\hline & Policy points & Remarks \\
\hline 1 & $\begin{array}{l}\text { To incorporate DE operations UWI would function as a 'dual mode' } \\
\text { institution. }\end{array}$ & $\begin{array}{l}\text { Has not } \\
\text { happened. }\end{array}$ \\
\hline 2 & $\begin{array}{l}\text { Consequently, DE would become an integral part of staff } \\
\text { workload/normal duties. }\end{array}$ & " \\
\hline 3 & $\begin{array}{l}\text { 'Dual mode' would not be restricted to academic arena only, but would } \\
\text { apply to administration as well. }\end{array}$ & " \\
\hline 4 & $\begin{array}{l}\text { In delivering DE, priority would be given to print material supported by } \\
\text { local tutorials and audio and videoconferences. }\end{array}$ & $\begin{array}{l}\text { Is } \quad \text { being } \\
\text { followed (minus } \\
\text { video bit). }\end{array}$ \\
\hline 5 & UWIDEC to enrol 2000 students by 2002. & $\begin{array}{l}2000+\quad \text { since } \\
1999 .\end{array}$ \\
\hline 6 & Consideration would be given to 'mature students'. & $\begin{array}{l}\text { Not done de } \\
\text { facto }\end{array}$ \\
\hline 7 & There would be no provision for 'open entry'. & Being followed. \\
\hline 8 & $\begin{array}{l}\text { DE in campus countries would be the concern both of the three Campus } \\
\text { Principals and of the BNCCDE. }\end{array}$ & $\begin{array}{l}\mathrm{DE} \text { is only } \\
\text { BNCCDE's } \\
\text { concern. }\end{array}$ \\
\hline 9 & $\begin{array}{l}\text { Among others, UWIDEC's staff would include specialists in such } \\
\text { instructional formats as are used for the Internet. (This is obviously a } \\
\text { later interpolation.) }\end{array}$ & $\begin{array}{l}\text { Internet experts } \\
\text { never thought } \\
\text { of. }\end{array}$ \\
\hline 10 & $\begin{array}{l}\text { "The professional faculties/schools are the natural home for professional } \\
\text { continuing education, while some of this work will involve the DEC ... }\end{array}$ & $\begin{array}{l}\text { The position is } \\
\text { not clear. }\end{array}$ \\
\hline
\end{tabular}




\begin{tabular}{|c|l|l|}
\hline 11 & $\begin{array}{l}\text { much will not, and there is no particular reason to try to organise it as if it } \\
\text { did." }\end{array}$ & $\begin{array}{l}\text { BNCCDE offers 'a platform for the exchange of ideas and plans between } \\
\text { the faculties, campuses, and the specialised outreach units under the } \\
\text { Board, so that duplication is avoided and emerging needs are attended } \\
\text { to'. }\end{array}$ \\
\hline 12 & $\begin{array}{l}\text { DE operations would be under Centre Budget in order that on-campus } \\
\text { students subsidise them. }\end{array}$ & $\begin{array}{l}\text { Principals don't } \\
\text { agree. }\end{array}$ \\
\hline 13 & $\begin{array}{l}\text { As campuses incorporate 'dual mode', funding for DE will become more } \\
\text { and more prominent in campus budgets. }\end{array}$ & $\begin{array}{l}\text { Has not } \\
\text { happened. }\end{array}$ \\
\hline 14 & $\begin{array}{l}\text { UWIDEC course fees would be close to those for on-campus students- }- \\
20 \% \text { of the economic cost }\end{array}$ & $\begin{array}{l}\text { Computation not } \\
\text { clear. }\end{array}$ \\
\hline 15 & $\begin{array}{l}\text { DE income during the initial period would be used for developing DE. } \\
\text { Being followed. }\end{array}$ \\
\hline 16 & $\begin{array}{l}\text { UWIDEC budget was increased from J\$23.5 million in 1993/94 to J } \$ 143 \\
\text { million in 1998/99. }\end{array}$ & $\begin{array}{l}\text { J } \$ \text { million } \\
\text { for } \\
\text { students is faulty } \\
\text { estimation. }\end{array}$ \\
\hline
\end{tabular}

(Koul, 2003)

\section{Table 2}

\section{Status of UWIDEC Operations (1998)}

\begin{tabular}{|l|l|l|}
\hline 1 & $\begin{array}{l}\text { Operations } \\
\text { Initiative for policy articulation and change lies with UWIDEC and The } \\
\text { Office of BNCCDE. } \\
\text { Responsibilities of UWIDEC - management of network and course } \\
\text { delivery, facilitating departments/faculties in planning and production of } \\
\text { courses, etc..... }\end{array}$ & $\begin{array}{l}\text { UWI regulations } \\
\text { do not allow it. } \\
\text { Can't be } \\
\text { fulfilled without } \\
\text { related powers. }\end{array}$ \\
$\begin{array}{l}\text { Academic aspects remain the responsibility of faculties and the other two } \\
\text { Boards. For any course to be launched the faculty has to agree and } \\
\text { implement. }\end{array}$ & $\begin{array}{l}\text { An undefined } \\
\text { area, so slipshod } \\
\text { work. }\end{array}$ \\
$\begin{array}{l}\text { UWIDEC is responsible for initiating and sustaining the necessary } \\
\text { dialogue among the campuses in case the disciplinary areas are found at } \\
\text { more than one campus. }\end{array}$ & $\begin{array}{l}\text { AWIDEC can't } \\
\text { bring them to a } \\
\text { consensus. }\end{array}$ \\
Courses to be parallel to those on campuses. & Being followed. \\
\hline
\end{tabular}




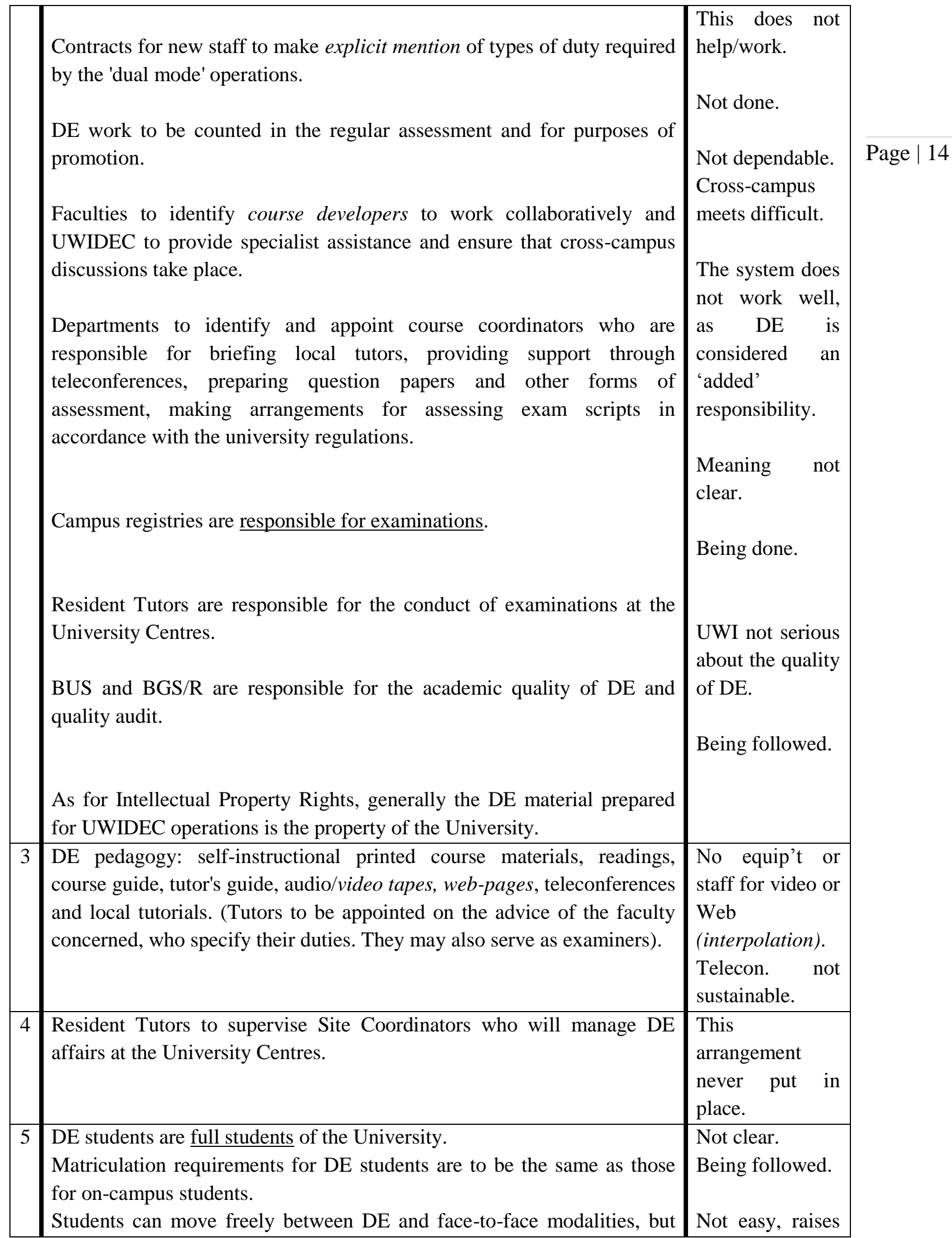




\begin{tabular}{|l|l|l|}
\hline & $\begin{array}{l}\text { such movement is subject to the availability of seats and other resources } \\
\text { at the receiving end. } \\
\text { Student support system and personnel in position to help students. }\end{array}$ & $\begin{array}{l}\text { problems. } \\
\text { This had to be } \\
\text { forced in. }\end{array}$ \\
\hline 6 & $\begin{array}{l}\text { University Librarian has responsibility for DE students and libraries in } \\
\text { NCCs. }\end{array}$ & $\begin{array}{l}\text { Some effort } \\
\text { visible. }\end{array}$ \\
\hline 7 & $\begin{array}{l}\text { Training Committee to take care of training activities for all categories of } \\
\text { staff. }\end{array}$ & \begin{tabular}{l} 
Doesn't exist. \\
\hline
\end{tabular}
\end{tabular}

(Koul, 2003)

As Koul further notes,

Of the 37 policy and implementation points, 29 points show 'negative' status....Its [UWIDEC] role has mainly been that of crises management, because the University launched an operation for which the necessary mechanisms had not been created, the required personnel had not been put in place, [for example, i) no staff was provided to handle course materials for about 2500 students - at an average of 90,000 items (3 courses per learner $\mathrm{x} 3$ items per course $\mathrm{x} 4$ instalments per semester) and ii) computer labs were set up without any technical support to keep them fully functional] and the whole operation had not been underwritten appropriately. (p. 3)

A chronological examination of the proposals for the re-engineering of UWIDEC are contained in a series of reports presented to the Board for Non-Campus Countries and Distance Education (BNCCDE) from as early as October, 1998. The 1998 UWIDEC report presented to the BNCCDE emphasized the following:

...that UWIDEC is in a precarious situation (it has neither the authority to help learners and/or Centres/Sites out of their difficulties nor the power to purposefully influence the faculties and/or the administration) and that there was an urgent need for an overhaul as nothing short of an overhaul can help the distance education enterprise at UWI. (p. 3)

Nineteen operational facts/problems (related to the operational environment, process of admissions, study materials, tutors, course writing, etc.) were identified to be detrimental to DE operations, and 37 minor and major proposals were put forward to solve them. Koul (2003) reported that only a few of these were approved for implementation, many were met with incomprehension, and some were scoffed at (e.g., concern about delays in examination results). Some were submitted to the Board for Undergraduate Studies (BUS) for consideration and action, and the BUS response was as revealing as it was disappointing. It was revealing to learn that BNCCDE was functioning on the periphery as a subordinate board, that DE operations were governed by regulations established decades ago for campus-based students, and that to effect any reform one had to appeal to faculty boards, academic boards, BUS, and Board for Graduate 
Studies and Research (BGSR) then wait for global consensus. However, it was disappointing that issues like 'pending examination results' were dealt with indifferently by as responsible a body as BUS. For example, "The Board was asked to note that the late submission of grades by Examiners caused disruption at the start of the Semester" (Minute 67.1, BUS Meeting of February 10, 1999). Koul (2003) recalls that the overall response of the BNCCDE was the admonition that UWIDEC should "articulate alternative models for the fundamental ordering of distance education at UWI" (p. 4). In weighing the alternatives available in such a difficult environment for DE, Koul concludes that, "We had either to give up or persist; we chose the latter course of action" (p. 4).

According to a report presented to the first meeting of the University of the West Indies Distance Education (UWIDEC) Academic Programme Committee, a note presented at a BNCCDE meeting in the Cayman Islands in 1999 spoke of the need for articulation of an alternative model since UWIDEC “experienced deeper fissures in the system" (p.4). UWIDEC identified four broad problem areas: administrative, financial, technological, and academic. Koul highlighted five distinct cases pertaining to administration, which made it clear to the Board that "DE students were treated as if they were nobody's concern" (p. 4). He further recalled six cases related to financial operations that exposed the tendency to count DE students as UWIDEC students rather than UWI students (the implications being obvious). In addition, mention was made of five technology cases that revealed the vulnerability of UWIDEC in this area. Finally, five cases related to academic matters showed that DE work was seen as an add-on and that "so long as DE work is not seen as and arranged to be an integral part of an academics' mandate at UWI, the Faculty Driven Model remains a myth to be exalted in rhetoric and denigrated in practice" (p. 4). Reformative proposals were listed for each of the four areas. Koul stated that the discussion was extensive and some of the proposals were accepted for implementation, but most had implications for various units and Boards of the University. He concluded that "Not enough progress was made" (p. 4).

In 2001, at the BNCCDE meeting in the Turk and Caicos, UWIDEC brought forward a detailed proposal, which focused on academic management, administration, financial management, and maintenance of standards/quality assurance. A work plan indicating the timeframe and individuals/units to share responsibilities for the implementation of the proposal was also included for consideration. The ensuing discussion brought forth various suggestions, and the proposal met with approval for further action. One of the major follow up action points was to share the proposal with and seek (as appropriate) the views, agreements, and/or approvals of UWIDEC and SCS staff, the Executive Management Committee, and the University Bursary. By and large, the proposal was supported by all of the relevant bodies. Among other items under academic management, a separate body, UWIDEC Academic Programme Committee, was proposed to look after the academic affairs of UWIDEC, but the budget design was to be developed.

Koul makes the point that having incorporated the inputs and comments received from the relevant quarters, a revised note regarding the proposed new governance of UWIDEC was presented to the Board at its meeting on May 10, 2002, in Dominica. An elaborate note on the 
new UWIDEC budget design, the size of the required budget provision including that for technology (which was non-existent in the then present provision), elaborated detail of the timeframe, the required staff provision, and details regarding the allocation and placement of the proposed staff was presented. The document met with appreciation and attracted approval for further concomitant action. The relevant documentation was submitted to and discussed with the University Bursary for their consideration and action, and as Koul concludes "here we are commencing with the new governance" (p. 5).

However, despite this gloomy assessment of the operations of UWIDEC, student evaluations have shown that graduates did perform well, and in some instances, achieved better results than those students enrolled in the face-to-face mode.

The limitations mentioned above contributed in part to the motivation to create a fourth campus, which would favour distance learning and streamline the operations of UWI's outreach efforts. However, the idea for the creation of a fourth campus was not new. Bird (1984) cites Ramesar (1978) as one who had "called for a reopening of the idea of establishing within the university of an additional campus - an Open Campus - to address itself to three distinct areas of activity" (p.419). In July, 1992, the Appraisal Report of the Caribbean Development Bank spoke to several different types of issues that needed resolution if outreach activity and distance education at UWI were to grow in desirable ways. The document refers to the recommendation of the Renwick et al. Report, which saw the issue as a choice between dual mode and some form of autonomous distance education operation, what has often been referred to as a fourth campus. It emphasized that just as each campus was able to propose programmes and arrangements with Tertiary Level Institutions (and is now able to decide upon such matters independently, though within general policy guidelines set by the new Board for Undergraduate Studies), a fourth campus for distance education would propose programmes, enter into agreements with other providers, and employ people to carry out its work, either full-time or as part-time consultants from one or other of the campuses or other tertiary institutions. The document further claims that this would centralize planning for distance education and permit greater flexibility than some campus-based faculties would be willing to countenance. The document concludes that Renwick et al. rejected this option on the ground that it would forego the opportunities for mutual enrichment of the on- and off-campus programmes. It might also open the door to a belief that the distance education programme was of lesser stature than the on-campus one. Dual mode was intended to provide the assurance that neither modality was superior; neither would be given preferential treatment. Even thoughUWI had opted for the dual mode operation in 1996, demands on the institution by stakeholders and the policy and implementation weaknesses highlighted by Koul dictated that they reverse the earlier decision to embrace the concept of a fourth campus, which would be autonomous in terms of its overall operations.

Koul's view is not without support in the debates about dual mode institutions. One of the key factors that has impeded the development of a fully integrated dual mode system of delivery in some traditional face-to-face institutions has been resistance from the academic staff, a factor alluded to earlier in this paper in reference to UWI. This resistance may be born out of "concerns about additional workload; perceptions of the status of external students vis-a-vis their full time 
counterparts; or the fact that the design and development of distance teaching materials carries little weight in terms of career path aspirations" (Freeman, 2004, p. 50). Moran and Myringer (1999, p. 62) suggest that the resistance is born of insecurity and the tension that exists between the academics' desire to offer individualized learning and the standardization that is inherent in self-instructional learning packages. Faculty alienation can arise from a perceived loss of authority and a sense of redundancy that is often compounded by a skills and knowledge gap in matters related to advanced technology and curriculum development, a situation which should be addressed by staff development. Olcott and Wright (1995) propose a further list of barriers: Distance education is considered inferior to traditional face-to-face teaching; faculty members have a perception of inadequate compensation, training and incentives for DE programmes; and there is a lack of institutional support. They conclude that without an administrative infrastructure to support distance teaching faculty, the barriers will outweigh the incentives.

In 2003, the Commonwealth of Learning (COL) issued a pamphlet in its Knowledge Series, Open and Distance Learning Policy Development (Particular Reference to Dual Mode Institutions), in which it notes that a policy environment friendly to open and distance education delivery and practice must contain the following values:

- Commitment to maintaining academic quality and standards in all programmes, irrespective of mode of delivery;

- Equal consideration for student, professional, and community esteem across all modes of delivery;

- Guaranteed access for DE students and faculty to a range of services comparable to those available for on-campus students;

- Sufficient training for and numbers of staff to successfully deliver DE programming;

- Commitment to providing or finding financial resources for the DE programme. (Bottomley and Calvert, 2003, p. 6)

Earlier, Koul (2000, p. 236) had identified 15 areas of dysfunction caused by the unrealistic nature of the basic assumptions that underpinned the original planning process at UWI. These areas are summarized here:

- The model assumed that all faculty had $20 \%$ of unused time that they could devote to DE operations. Faculty disputed this, though they would have been willing to work for DE in their own time for extra pay;

- Administrative units did not uniformly accept responsibility for DE related work, to the extent that DE students are not counted as those of the university and they are treated indifferently;

- Existing rules and regulations are insensitive to the needs of DE students, leading to bitterness and disaffection among the students;

- Faculty indifference or antagonism results in poor quality delivery to DE students, and a strong faculty power base results in a 'toothless' DE Centre without authority to demand results; 
- Failure to cost services properly and lack of understanding of or concern for DE operations leads to inefficient use of funds;

- Low priority given to DE work leads to delays and results in a poor reputation;

- The special board created to oversee DE is subservient to other senior boards that are well recognized and well entrenched within the institutional ethos, so that its power to effect change is severely hampered;

- DE work is given no place in the scheme of career advancement in the university and is therefore scoffed at;

- Conflicts between faculty and instructional designers lead to delays in course production and delivery;

- Mandated local tutorial support is not always available at all local centres.

The consequences for the students were inevitable:

- Confusion with registration, selection of courses, and award of exemptions;

- Delayed and/or piecemeal supply of study materials, defective instructional design, and confusion in assignment handling;

- Confusion in the organization of teleconferences, absenteeism among course coordinators, local tutors, and students, and indifference to learners' enquiries;

- Delayed appointment/non-availability of tutors and demotivating size of tutorial groups;

- Confusion in the conduct of examinations, distribution of wrong question papers, loss of answer scripts, problems with remarking or review of scripts, inordinately delayed and lost results.

Koul's prescription for corrective action includes the following:

- The establishment of an effective and well documented quality assurance system relating to academic and administrative functions;

- A concerted effort to bolster the key major operations that DE depends on - support services, course preparation, dispatch and distribution of materials, recruitment and training of tutors, accurate scheduling of teleconferences, and top level functionality of the digital network;

- Modification of relevant rules, regulations and related practices, and associated changes to administrative structures and work culture;

- Dedicated and independent budgeting to ensure appropriate investment in DE;

- Investing in technology and training to maximize the use of technology mediated learning; and

- Establishing a board that is able to formulate policies and implement them effectively.

The existing board merged with the other entities within the outreach sector to create a single entity, which it was anticipated would successfully address the issues raised by Koul. This entity would take the form of a fourth campus, an open campus of The University of the West Indies. 
The newly created fourth campus will merge the three existing arms of the outreach sectors of The University of the West Indies: The UWIDEC, TLIU and the SCS with its five specialized units of the Caribbean Child Development Centre (CCDC), the Hugh Lawson Shearer Trade Union Education Institute (HLSTUEI), the Human Resources Development Unit (HRDU), the Social Welfare Training Centre (SWTC) and the Women and Development Unit (WAND). The merged entity will be an amalgamation of some 42 sites spread across the Caribbean.

The student-centred Open Campus will employ the use of a range of methodologies and formats in the delivery of its programmes, including blended learning modalities, face-to-face, online, and distance, and involving the distribution of print and software materials. These include preuniversity education courses, certificate, diploma, and undergraduate programmes and courses, post-graduate degree programmes, distance education courses, extension courses, technical and vocational courses, and other lifelong learning activities. As mentioned earlier, John Daniel (2007) noted his reservations about the blending of distance and classroom learning to solve the problems encountered by dual mode institutions. This is highlighted when he states that “...some would say that the blending of distance and classroom learning through eLearning has made this distinction irrelevant". He opined that although this may be true, dual-mode eLearning raises another fundamental question: "Does not the cottage-industry approach to eLearning through dual-mode operation effectively ensure that this powerful new tool performs below potential?" (p. 3). Further, Daniel makes the point that those who believe one of the fundamental missions of distance learning is to improve access should also worry that eLearning is diverting attention and resources away from disadvantaged students and back to those who are already well served. He questions whether eLearning is another example of "the empire striking back, with traditional academe undermining attempts to widen access?" (p. 3). This confirms the view mentioned above that in the case of the UWI, the best model is yet to be found.

Nonetheless, UWI Open Campus (UWIOC) has begun the processes for further development, working within the constraints of a budget that has not provided adequately for the extensive work to be undertaken in establishing a campus. Despite these imposed constraints, UWI Open Campus staff increased their efforts to meet the agreed-upon targets of achieving full implementation by September, 2008, and progress has been made with respect to the preparation of a unified UWI Open Campus budget for consideration at the Technical Accounts Committee (TAC) meetings held in February, 2008. In addition, the Campus a completed detailed assessment of its development needs for the purpose of preparing grant proposals for submission to funding agencies. Without additional resources from external sources, it would be difficult for the Campus to fund the technological enhancements required at existing sites. In the interim, UWI Open is accessing resources for technological development support through partnerships with agencies such as the Caribbean Knowledge and Learning Network (CKLN) for the provision of services (e.g., training). The Campus is working to improve the partnership arrangements even as it explores other avenues for funding. 


\section{Organizational Structure of the Open Campus}

The organizational structure of UWI Open is based on the imperatives for efficient functioning within a distributed environment. These include the entities indicated in Figure 1, in which Student Services is centrally placed and is the focus of the other units that form the organizational structure of UWI Open. In keeping with the concept and the vision articulated for the Open Campus, the existing outreach sectors, namely the School of Continuing Studies, with the sites established in the UWI-12 as well as the sites existing in communities within countries with established campuses, the Tertiary Level Institutions Unit, and The UWIDEC, are incorporated and integrated into the campus structure to facilitate efficient functioning and delivery of services. Accordingly, UWI Open will comprise 10 functional units that will be responsible for the management of the affairs of the campus and for the delivery of its services. These are: (i) the office of the Principal; (ii) the office of the Deputy Principal; (iii) the office of the Director of the Open Campus Sites in the region; (iv) the office of the Director of Academic Programming; (v) the office of Student Services managed by the Registrar; (vi) the Division of Computer and Technological Services; (vii) Library and Information Resources; (viii) the office of the Director of External Relations and Inter-Institutional Relationships;(ix) the Consortium of Social Research and Development and (x) the office of Finance and Administration. Figure 1 is the most recent version of the structure circulated to staff of the Open Campus and staff of the sister campuses for input and suggestions.

\section{Chart 1 - An Organizational Structure - Based on Functional Imperatives}

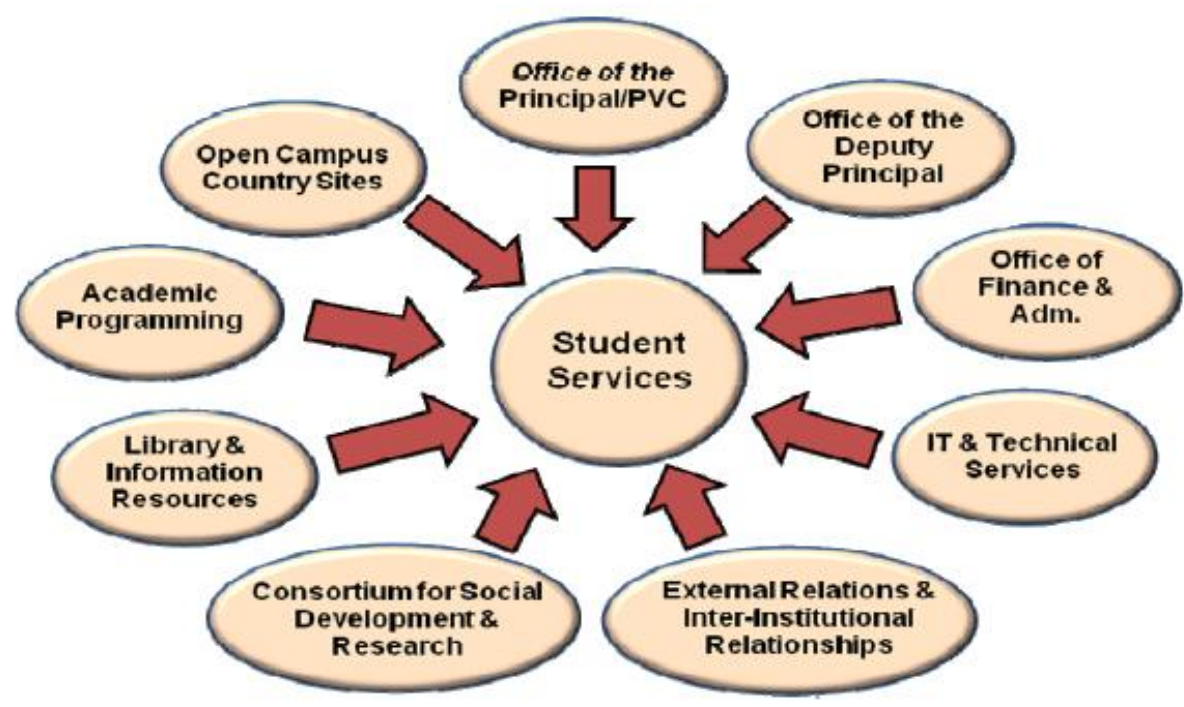

Figure 1. An organizational structure based on functional imperatives. Adapted from The University of the West Indies Open Campus Progress Report, 2008.

These structures are not stand-alone in the operational sense but are functionally linked with respect to what must be performed and the collaboration required for the efficient delivery of services. 
The managerial functions are represented by Figure 2 below and represent some existing positions within the existing entities to be merged as well as some newly created ones. Some positions are also expected to be filled by a redeployment of existing staff.

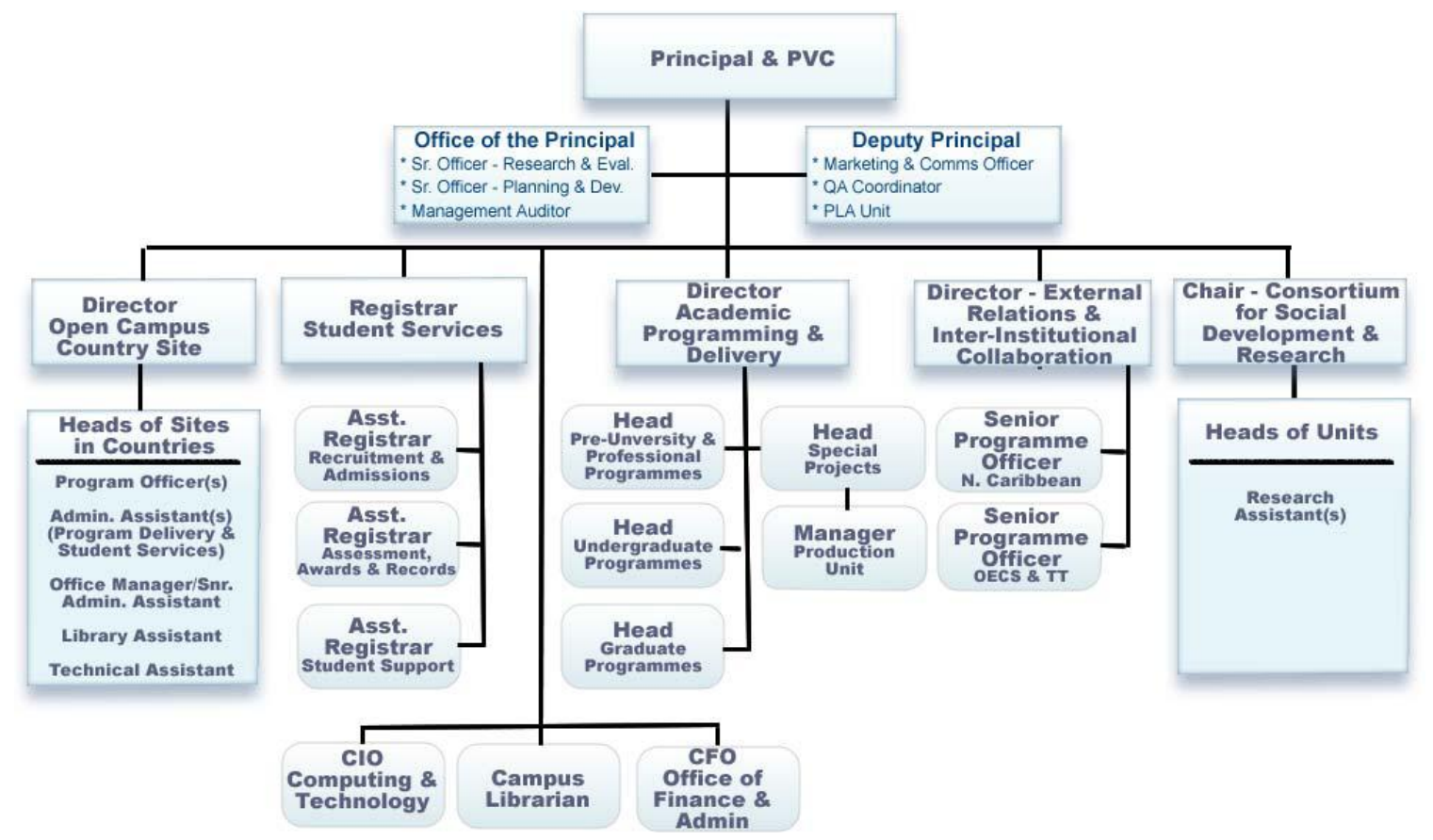

Figure 2. Open Campus Organizational Chart. Source: Adapted from The University of the West Indies Open Campus Progress Report, 2008.

It is proposed that the directors/chairs and senior administrative staff of UWI Open will comprise the management/steering committee of the campus with heads/managers/officers co-opted on the basis of items tabled for discussion on the agenda of monthly management meetings.

UWIOC, which has been described by principal, Professor Hazel Simmons-McDonald, as "a campus for the times and a campus for the future", will enjoy the same level of autonomy as other UWI campuses with its own Academic Board, financial management, registry, administrative, and student support systems. Within this structure, UWIOC will function as a network of real and virtual modes to deliver education and training to anyone with access to Internet facilities. That physical presence in each contributing country will be enhanced to permit services that are more appropriately provided through face-to-face delivery. UWIOC will deploy the technological and instructional design capabilities of the staff in what is now UWIDEC to permit the blending of online and face-to-face learning experiences that enrich the social aspects of learning in a collegial environment. It will build on the record and work of the TLIU to facilitate the interaction of the UWI with other universities, colleges, educational institutions, and scholars as part of a movement towards a seamlessly linked education system for the development of the Caribbean region. The Open Campus will continue to enhance the work of the School of Continuing Studies in responding to local needs and in fostering social and cultural development. 
The Open Campus will be governed by a Campus Council in keeping with the statutes and ordinances of The UWI, adjusted to accommodate its virtual character. The Campus will draw its intellectual sustenance from the entire academic array of the existing campuses, and like them, will also draw upon external resources where necessary. Its organization will be driven by the functions required for the effective delivery of its programmes, of teaching, of research, and of consultancy. Students of the Open Campus will enjoy the same quality of instruction and receive the same qualifications as students in the three fixed campuses even though the nature of instructional practice might entail differences in the management of their studies and their scholarly experience.

The programmes of the Open Campus and its academic operations will be governed by its Academic Board, subject to the overarching authority of the Boards for Undergraduate Studies and for Graduate Studies and Research. A new Finance and General Purposes Committee will fulfill the mandate of Council in the affairs of the campus. Accordingly, separate administrative and financial bodies will manage the affairs of the campus, subject to the established reference points of the financial code and the body of UWI administrative practice.

The Revised Draft Strategic Plan 2007-2012 outlines the aims, strategies, timelines, milestones, performance indicators, and the anticipated outputs of UWIOC, which include the following: increased opportunities for access, increased enrollment in UWI-12 countries, improved retention and completion rates for all students, more flexibility and convenience in access, broadened scope of research, and generally higher satisfaction levels for students in both underserved and served communities. All of this will be made possible through the formulation of policies that focus on centralization in the UWIOC of the development, management, and delivery of the UWI distance offerings, decisions on the procurement and development of UWI distance learning programmes, campus-specific policy related to open admission, internal stakeholder agreement on collaboration, roles and responsibilities of the four campuses, and issues related to cost of service and fees.

\section{Conclusion}

The UWIOC is to be seen as The UWI's commitment to addressing the region's development imperatives in ways that will transform the regional pattern of development from one that is principally dependent on natural resources to one that is dependent on human resources and knowledge. In so doing, it will widen its role as a catalyst for change and an instrument of development by providing the services needed in the region to facilitate personal, intellectual, and professional growth and to enhance the economic, social, and cultural development of the peoples of the region.

In establishing this campus, after merging the three critical units that comprise the Outreach sector, The UWI has begun to consolidate the institution's scarce managerial, academic, and professional skills, reduce the high levels of duplication endemic in Caribbean higher education, and provide greater opportunities for lifelong learning to thousands of underserved students. In 
addition, the understanding of the need to expand the scope of research and to introduce new research projects signals the institution's intention not just to create an institutional research agenda and to encourage academic research, but also to assist in the crafting of a regional development agenda for the governments of the region. In this way, the Open Campus is well positioned to contribute to the existing body of literature on issues relating to educational theory, open and distance learning, and higher education administration and policy. It will also be well placed to comment on and contribute to evaluation studies and formal research on which future open and distance learning projects can be built.

The Campus, according to the Vice-Chancellor, is designed "to capitalize on advances in online technologies and on the platform of 50 sites...to advance a more student-friendly, much broader basket of degree, diploma and certificate programmes for Caribbean people" who live beyond the walls of the institution (Caribbean Net News, 2008). The Open Campus will be invaluable in extending access to underserved groups of learners in those countries without campuses, to groups in some campus countries who are located in remote areas, and to groups of diasporic Caribbean students. It has the potential to become the largest sector in terms of a pool of students among the other campuses and the opportunity to defend the DE market share in face of the burgeoning competition from international and virtual institutions. It will also be critical in enhancing the tertiary sector to reach beyond the region and into the Caribbean diaspora.

However, successful DE providers have learned that while technology can facilitate low cost access to and delivery of content, effective student support in the form of systematic interaction between teacher and learner is a necessary component of all successful programmes and is by no means inexpensive (Ryan and Stedman, 2002, p. 46). In addition, moves from face-to-face or traditional DE to online education represent significant changes in the assumptions of teachers, learners, and support staff and to the technological infrastructure and skill base that support this migration. Achieving a migration from the post-box and hard text delivery of conventional DE to online learning requires at least three preconditions. First, the technical infrastructure needs to be transparent to users. Second, its operational framework must address teaching and learning decisions when it describes its functions. Third, systematic and local professional development in online teaching and learning using a "just-in-time" and "just-for-me" approach must be available to academics (Nunan, Reid \& McCausland, 2002, p.10).

Although these may not be guarantees of future success, two strategies are available to small and medium-sized universities, such as UWI, as they embrace open and distance learning modalities in a competitive environment: the provision of value-added differentiating services and the development of a recognizable brand. The first can be achieved by assigning as much importance to the open as to the distant in ODL and by establishing flexibility in the following areas: admission criteria; programme regulations (recognition of prior learning, block transfer, residency, time for completion); course design (individualized and self-paced learning modules, minimal course prerequisites); course availability (uncapped and continuous enrolment); and responsive institutional structures (for approval of new programs, learner-centred academic regulations, and continuous improvement). The second strategy, recognizable branding, can be 
achieved by emphasizing quality, not just in academic content and exchange, but in all student support services, so that learners are treated more and more like valued customers.

Overall, the new entity is expected to make a significant contribution towards the understanding of open and distance learning issues and theory, especially in the context of the Caribbean region. 


\section{References}

Albrect, D. \& Ziderman, A. (1994). Funding mechanisms for higher education: Financing for stability, efficiency and responsiveness. Discussion Paper \# 153. Washington D.C.: World Bank.

Anderson, D. et al. (1998). Access to postgraduate courses: opportunities and obstacles. Canberra: Australian Government Publishing Service.

Bird, E. (1984). The University of the West Indies in the 1980s. Prospects: Quarterly Review of Comparative Education, XIV(3), 413-422.

Bottomley, J. and Calvert, J. (2003). Open and distance learning policy development (particular reference to dual mode institutions). Vancouver, Canada: Commonwealth of Learning. Retrieved February, 2009, from http://www.col.org/colweb/webdav/site/myjahiasite/shared/docs/KS2003 policydev.pdf

Canino, M. J. (2002). Bridging walls and crossing borders in the Caribbean. Academe, 4 (1).

Carribean Net News (2008, July 8). New UWI Open Campus officially launched. Retrieved February, 2009, from http://www.caribbeannetnews.com/education/education.php?news id=9006\&start=40\&c ategory_id=41

Carrington, L. D. and M. L. Thomas. (2001). The state of virtual education in the Commonwealth Caribbean: A preliminary study. Barbados: The University of the West Indies.

Daniel, J. (2007). Reflections on a career in distance education. In Learning for development: Selected speeches of Sir John Daniel and colleagues: January, 2007. Vancouver, Canada: Commonwealth of Learning. Retrieved February, 2009, from http://www.col.org/resources/speeches/2007presentations/Pages/2007-01-reflections.aspx

Ellis, E.M. (2000). Faculty participation in the Pennsylvania State University World Campus: Identifying barriers to success. Open Learning, 15(3), 233-242.

Fergus,H., Bernard, L., \& Soares, J. (2007). Breaking down the Walls: An Evolution of the ExtraMural Department The University of the West Indies 1947-2000. Jamaica: School of Continuing Studies.

Freeman, R. (2004). Planning and implementing Open and Distance Learning systems: A handbook for decision making. Vancouver, Canada: Commonwealth of Learning.

Geetha, Rani, P. (2004). Economic reforms and financing higher education in India. Indian 
Journal of Economics and Business, 3(1), 79-102.

Gulati, S. (2008). Technology-enhanced learning in developing nations: A review. International Review of Research in Open and Distance Learning, 9(1). Retrieved February, 2009, from http://www.irrodl.org/index.php/irrodl/article/view/477/1011

Kamau, J. W. (2001). Developing course materials: A context of technology constraints. In E. J. Burge \& M. Haughey (Eds.), Using learning technologies: International perspectives on practice (pp. 48-60). London: Routledge Falmer.

Koul, B.N. (2000, July). Dystopia to utopia and beyond: A case for distance education $(D E)$ in small states. Paper presented at The University of West Indies Small States Conference. Retrieved February, 2009, from http://www.col.org/colweb/webdav/site/myjahiasite/shared/docs/2_conf_proc_Koul.pdf

Koul, B.N. (2003, March). UWIDEC Academic Programme Committee: Genesis, Composition and Function. Paper presented at the first meeting of the UWI Distance Education Centre (UWIDEC) Academic Programme Committee, The University of the West Indies, Barbados.

Lalor, G.C \& Marrett, C. (1986). Report on The University of the West Indies Distance Teaching Experiment. Mona, Jamaica: Senate House University of the West Indies.

Lewins, K. M., \& Stuart, J. S. (Eds.). (1991). Educational innovation in developing countries; Case studies of change makers. London: Macmillian.

Malik, N. A., Belawati, T., \& Baggaley, J. (2005). Framework of collaborative research and development on distance learning technology for Asia. Paper presented at the 19th Annual Conference, Association of Asian Open Universities, Jakarta, Indonesia. Retrieved June 9, 2007, from, http://www.pandora-asia.org/downloads/05AAOU_MalBelBag.pdf

Marrett, C. (2000). Considerations in implementing distance education in the Caribbean. In Caribbean perspectives (pp. 3-6). St Thomas: University of the Virgin Islands.

Marrett C., \& Harvey, C. (2001). Getting the systems right. In E. J. Burge \& M. Haughey (Eds.), Using learning technologies: International perspectives on practice (pp. 38-47). London: Routledge Falmer.

Marshall, W (1997/1998). Some issues in UWI's outreach. Board for NCCS \&DE News, 1(1) Retrieved February, 2009, from http://cavehill.uwi.edu/bnccde/docs/BDNEWS1.html 
Miller, Errol. (2000). Access to tertiary education in the Commonwealth Caribbean in the 1990s. In Glenford Howe (Ed.), Higher education in the Caribbean: Past, present and future directions (pp. 117-141). Kingston, Jamaica: The University of the West Indies Press.

Miller, E., Jules, D., \& Thomas, L. (2000). Pillars for partnership and progress: The OECS education reform strategy: 2010. Castries St. Lucia: OECS Education Reform Unit. Retrieved February, 2009, from http://www.oecs.org/oeru/documents/Pillars\%20for\%20Partnership\%20and\%20Progress. pdf

Morgan, P. (2000, July). Strengthening the stakes: Combining distance and face to face teaching strategies - preliminary discussion issues. Paper presented at the Distance Education in Small States conference, Ocho Rios, Jamaica. Retrieved February, 2009, from www.col.org/resources/publications/SmallStates00/2 conf_proc Morgan.ppt

Moran, L., \& Myringer, B. (1999). Flexible learning and university change. In K. Harry (Ed.), Higher education through open and distance learning. World review of distance education and open learning: Vol. 1 (pp. 57-71). London: Routledge.

Nunan, T., Reid, I., \& McCausland, H. (2002). Global perspectives: The University of South Australia (UniSA) case study. International Review of Research in Open and Distance Learning, 2(2). Retrieved February, 2009, from http://www.irrodl.org/content/v2.2/mccauslandetal.htm

Olcott, D.Jr. and Wright S.J. (1995). An institutional support framework for increasing faculty participation in postsecondary distance education. The American Journal of Distance Education 9(3), 5-17.

O’Neal, M. and Davies, H. (2000). Distributive education: The British Virgin Islands experience. In Caribbean perspectives (pp. 7-10). St Thomas: University of the Virgin Islands.

Organisation of Eastern Caribbean States Education Reform Unit Strategic Plan 2001-2010. (2001). Retrieved $\quad$ February, 2009, from http://www.oecs.org/oeru/documents/OERU\%20Strategic\%20Plan.pdf

Organisation of Eastern Caribbean States Education Reform Unit (2007). Reforming Tertiary Adult and Continuing Education.

Retrieved February, 2009, from http://www.oecs.org/oeru/inits_tertiary_edu.html

Pantojas-Garcia, Emilio (2000). Caribbean higher education: The challenge of distance learning. In Caribbean perspectives. St Thomas: University of the Virgin Islands. 
Hope, A. (2006). Factors for success in dual mode institutions. Vancouver, Canada: Commonwealth of Learning,

Ramesar, E. (1978) Recurrent issues in higher education in the Caribbean. In N.A. Niles \& T. Gardner (Eds.), Perspectives in West Indian Education (pp. 151-71). East Lansing, MI: West Indian Student Association, Michigan State University.

Roberts, Vivienne (1999). Access to tertiary education in selected Caribbean countries: Enabling and limiting factors. Unpublished doctoral dissertation, University of the West Indies, Barbados.

Roberts, Vivienne (2002). Overcoming barriers to access and success in tertiary education in the Commonwealth Caribbean. Paper presented at $2^{\text {nd }}$ Pan-Commonwealth Conference, Durban, South Africa.

Renwick,W., Shale, D., \& Rao, S. (1992). Distance education at the University of the West Indies: Report of an appraisal carried out on behalf of the Commonwealth of Learning. Vancouver: The Commonwealth of Learning.

Ryan, Y. and Stedman, L. (2002). The business of borderless education: 2001 update Canberra: Department of Education, Training and Youth Affairs. Retrieved February, 2009, from http://www.dest.gov.au/archive/highered/eippubs/eip02 1/eip02 1.pdf

Sherlock,P \& Nettleford,R. (1990). The University of the West Indies: A Caribbean response to the challenge of change. London and Basingstoke: Macmillan Publishers

Skilbeck, M. and Connell, H. (2000) Access and equity in higher education: An international perspective on issues and strategies. Dublin: The Higher Education Authority.

Talik, J. B.G. (2003). Higher education and development in Asia. Journal of Educational Planning and Administration, 17(2), 151-173.

Tewarie, B. (2007, Aug. 12). Expanding access and improving quality: A challenge that must be met. UWI Today, p. 9.

Universalia. (2004). Assessment of the CDB Student Loan Scheme (SLS), Final Report.

University of the West Indies. Revised Draft Strategic Plan 2007-2012.

UWI Tertiary Level Institutions Unit (2005). Human resource needs assessment of Caricom countries: The tertiary education sector response [Internal document]. Barbados.

UWIDEC/APC (2003, March 24). The first meeting of the UWIDEC Academic Programme 
Committee. Retrieved February, 2009, from

http://cavehill.uwi.edu/bnccde/APC/20021/APC2002-3P1.htm

Wint, A. (21-22, November, 2005). Financing tertiary education in the Anglophone Caribbean:

The role of student loan systems. Symposium conducted on Financing Tertiary Education in the Anglophone Caribbean, Barbados.

Woodrow, M. (1996). Quality equality. Project on access to higher education in Europe:

Working report. Part 1 - Synthesis and recommendations. Strasbourg: Council of Europe. 